\title{
СВРОПЕЙСЬКИЙ ТА УКРАЇНСЬКИЙ ВЕКТОРИ СТАНОВЛЕННЯ СИСТЕМИ ОСВІТИ В РОСІЇ ХVІІІ СТОЛІТТЯ
}

\author{
Мільто Л. О.
}

\section{ВСТУП}

Духовне відродження українського народу, формування державності, утвердження загальнолюдських цінностей не $\epsilon$ можливим без відродження історичної пам'яті, педагогічного досвіду, накопиченого людством за багато століть свого існування. На сучасному етапі розвитку українського суспільства гостро актуалізуються проблеми, пов'язані 3 культурою i просвітою. Особливого значення набуває питання взаємозв'язку науки і освіти, що пов'язане з розвитком сучасної науки, необхідністю притоку в науку високоосвічених фахівців, а також із розвитком освіти, що не може вдосконалюватися без взаємодії з наукою i використанням наукових досягнень.

Особливу актуальність ця тема має у зв'язку з необхідністю осмислення нових фактів i закономірностей історичного процесу. Виникає потреба критично осмислювати надбання минулого у сфері педагогічної теорії та практики та творчо використовувати їх здобутки. Уваги набувають дослідження в галузі історії освіти і педагогічної науки, вивчення конструктивних надбань, сформованих в історії педагогіки, його неупереджене оцінювання, виявлення продуктивних ідей і можливостей їх творчого використання. Результати і визначення перспектив подальшого розвитку педагогічної освіти потребують нової якості конкретно-історичних досліджень.

Методологічну основу дослідження становлять концептуальні положення системно-хронологічного, історичного, антропологічного, цивілізаційного, аксіологічного, культурологічного, історіографічного, персоналістично-біографічного підходів, а також діалектичні принципи (науковості, об’єктивності, історизму, системності, єдності теорії і практики).

Основою нашого дослідження $\epsilon$ історико-педагогічні праці з розвитку теорії й практики освіти Росії дореволюційного періоду (А. Воронова, М. Владимирського-Буданова, П. Каптерєва, Л. Модзалевського, П. Пекарського, С. Рождественського, М. Сухомлинова та інших) та сучасних дослідників (Л. Березівської, Н. Гузій, Н. Дем'яненко, Н. Дічек, Е. Днепрова, М. Свтух, Б. Корнетова, О. Лавріненко, С. Пономаревського, О. Сухомлинської та інших). 


\section{1. Українські чинники розвитку системи освіти в Росії}

Педагогічна наука епохи Просвітництва XVIII століття була зорієнтована на вдосконалення людини, сприяла становленню та розвитку теорії й практики освіти Росії. В епоху Просвітництва відроджуються гуманістичні ідеали, які проголошували ідею невід'ємного права людини у постійному розвитку інтелекту, а звернення науковців до питання про сутність людини актуалізували проблему виховання та розвитку особистості.

Становлення системи освіти Росії XVIII століття визначила радикальна європеїзація, ініційована Петром I, упровадження західного способу життя й утвердження культурних цінностей, які трансформували російські педагогічні традиції. Петровські реформації мали соціально-політичний i просвітницький характер. На думку М. Владимирського-Буданова, до Петра I панувала «елементарна система освіти», основу діяльності якої становили церковні приходи. Історик розглядав першу половину XVIII століття як період боротьби між духовною і спеціальною освітою, а другу - як період боротьби між спеціальною і загальною освітою ${ }^{1}$.

На становлення системи освіти в Росії значно впливали українські державні діячі-подвижники, науковці, просвітники, духовні особи. Важлива роль у цьому процесі належала Києво-Могилянській колегії, заснованій київським митрополитом П. Могилою в 1632 р. Відповідно до указу Петра I від 26 вересня 1701 р., колегія отримала статус академії й стала першим вищим навчальним закладом на східнослов'янських землях ${ }^{2}$.

Найбільш важливі дослідницькі роботи, присвячені історії виникнення Києво-Могилянської академії, з'явилися ще в дореволюційний період (В. Аскоченського, М. Булгакова, С. Голубєва, Н. Петрова, К. Харламповича та інших), які вказували на факт запозичення православними школами латино-польських освітніх ідей і висловлювалися про домінування латино-польського впливу в навчальних курсах Києво-Могилянської академії.

У цій академії навчалися С. Полоцький, С. Яворський, Ф. Прокопович, Г. Сковорода, М. Березовський, Д. Бортнянський, I. Григорович-Барський та інші українські просвітники, державні діячі, науковці, письменники, які вплинули на розвиток російської культури, освіти, науки.

Сучасний український дослідник С. Пономаревський акцентує увагу на тому, що впродовж майже усього XVIII століття в Росії значну

${ }^{1}$ Владимирский-Буданов М.Ф. Государство и народное образование в России XVIII века. Ярославль : Тип. Губернского Правления, 1874. Книга 8. С. 193-330.

${ }^{2}$ Мільто Л. Педагогічна майстерність в Росії: історія, теорія, практика (середина XVIII-XX ст.): монографія. Київ : «Фенікс», 2018. 612 с. 
частину інтелектуальної еліти становили українці за походженням, переважно випускники Києво-Могилянської академії. Учений зазначає, що представники цієї еліти не лише осідали в Москві або СанктПетербурзі, а й засновували школи, освітні й наукові центри в Сибіру, Алтаї, Уралі, Далекому Сході

Одним із результатів впливу Києво-Могилянської академії на культурний процес у суспільстві слід уважати поступову переорієнтацію на західноєвропейський курс розвитку освітньої політики. Ці ідеї втілились у планах Московської слов'яно-греколатинської академії - першого в Росії вищого навчального закладу, наукового й освітнього центру, де науки викладалися за зразком західноєвропейських університетів та колегій. Ініціативу іiі започаткування пов'язують із вихованцем Києво-Могилянської академії С. Полоцьким.

Слід зауважити, що Московська слов'яно-греко-латинська академія, на відміну від Києво-Могилянської, була ініціативою не духовенства, а царського двору, орієнтувалася на західноєвропейські навчальні заклади (університети, колегії) і готувала фахівців не лише для церкви, а й для потреб держави. Це свідчить про безпосередню зацікавленість світської влади раціоналізувати різні боки громадського життя за європейським типом. Випускники цієї академії згодом обіймали світські посади. Хоча цей заклад готував кадри не лише для церкви, а й для потреб держави, зокрема вчителів майже для всіх типів державних світських шкіл Росії, вона залишалася церковним закладом і була підпорядкована Синоду. Серед вихованців цієї академії були Л. Магницький, М. Ломоносов, В. Тредіаковський та багато інших діячів російської науки і культури.

О. Лавріненко звертає увагу на той факт, що в 1701 p. першим ректором Московської академії став С. Яворський, у 1704 p.С. Крайський (навчався в Києво-Могилянській академії з 1655 до 1656 рр., був ії викладачем), у 1706 р. - Ф. Лопатинський (вищу освіту здобув у Київській Академіï). Усього за 1701-1775 pp. 15 із 19 ректорів були вихованцями Києво-Могилянської академії. Саме діяльність науковців, педагогів, церковних діячів, що буди випускниками цього закладу, сприяла започаткуванню навчальних закладів у всій Російській імперії ${ }^{4}$.

Так, С. Яворський запрошував до викладання київських учених, серед яких були такі: Г. Бужинський, Г. Вишневський, С. Калиновський, В. Лащевський та інші. Оскільки багато професорів Києво-Могилянської

3 Пономаревський С.Б. Українське шкільництво у Росії (1917-2010рр.) : монографія. Чернігів : вид. Чернігівського державного інституту економіки і управління. 2012. $376 \mathrm{c}$.

${ }^{4}$ Лавріненко О.А. Історія педагогічної майстерності: навчальний посібник. Київ: Богданова А.М., 2009. 328 с. 
академії після іï закінчення продовжували свою кар'єру в Росії, то їх представляли як спільних українсько-російських діячів.

П. Пекарський, аналізуючи стан освіти в Росії XVIII століття, вказував на вплив київської ученості, перенесеної з Польщі, і вплив європейської освіти, перенесеної з Голландії, Німеччини, частково 3 Англії, Франції і навіть Італії.

П. Пекарський зауважив, що київські вчені (хоч і перейняті наскрізь схоластикою) були за своєю освітою незмірно вище московських книжників. На вивчення чужих мов, на читання чужомовних творів московські книжники дивилися як на збезчещення віри. Учений зробив висновок, що зародком всього, що відбувалося в історії науки та освіти в пізніший період, була заснована П. Могилою академія в Києві й діяльність Петра I для розповсюдження знань у Росії5.

Цікавою $є$ думка М. Трубецького (одного 3 найбільш авторитетних мислителів російського зарубіжжя, лінгвіста, філолога, історика, філософа, політолога) стосовно того, що Києво-Могилянська академія стала загальноросійським «розсадником» вищого духовного просвітництва, тому що більшість російських ієрархів довгий час були вихованцями саме цього закладу. Українською була і традиція постпетровської російської школи, зокрема «методів духу» й складу викладання.

M. Трубецький писав, що в Росії XVIII століття ще було прийнято висловлювати ті судження, які в XVII столітті висловлювали вченіукраїнці, тому культура, яка з часів Петра I живе і розвивається в Росії, $\epsilon$ органічним і безпосереднім продовженням не московської, а київської i, відповідно, української культури ${ }^{6}$.

У Києво-Могилянській академії, як стверджують дореволюційні й сучасні історики, деякий час навчався М. Ломоносов. Однак про подорож М. Ломоносова до Києва архівних документів не збереглося, навіть не $\epsilon$ відомою точна дата його перебування в закладі. Біограф М. Ломоносова, член-кореспондент Імператорської академії наук, член Російської академії наук М. Верьовкін писав, що М. Ломоносов звернувся з проханням до архімандрита відкомандирувати його на один рік до Києва навчатися філософії, фізики, математики, але пробув він там менше року, читаючи стародавні рукописи і книги, написані грецькою, латиною, слов'янською мовами.

Сучасний дослідник В. Данилевський у своїй книзі «Ломоносов в Україні» обгрунтовує приблизні дати його перебування в Києві (з літа 1773 р. до серпня 1734 р.). Як бачимо, в ті часи Московська академія перебувала під впливом київських учених, а система викладання була

5 Пекарский П.П. Введение в историю просвещения в России XVIII столетия. Санкт-Петербург : Тип. Акад. наук, 1862.578 с.

${ }^{6}$ Трубецкой Н.С. К украинской проблеме. Евразийский современник. Книга V. Париж, 1927. С. 165-184. 
орієнтована на київську традицію, тому рішення М. Ломоносова поїхати до Києва було цілком логічним ${ }^{7}$.

Багато київських учених працювали в Москві, зокрема Ф. Прокопович, внесок якого в розвиток культури й просвітництва (спочатку України, а потім i Росії) $є$ незаперечним. Слова Ф. Прокоповича «Нехай просвітництво хвилює вік» стали лейтмотивом усього його життя. Церковний і громадський діяч, філософ, письменник, учений, колишній ректор Київської академії, архієпископ Феофан (Слеазар) Прокопович був одним із засновників Російської академії наук.

Ф. Прокопович створив 3 учених, вихованців Києво-Могилянської академії С. Яворського, С. Кулябки, Г. Бужинського, Т. Кролика, так звану «вчену дружину», яка сприяла проведенню державних реформ, гуртувала навколо себе культурних діячів Росії, серед яких були В. Татищев, Я. Брюс, А. Кантемир, А. Волинський та інші.

Він був покровителем і другом багатьох академіків, виступав із проповідями в Олександро-Невській лаврі, вражаючи російську публіку красномовством, ерудицією та глибокодумними міркуваннями. Літературна й ораторська діяльність Ф. Прокоповича в Санкт-Петербурзі була спрямована на втілення політичних, церковних і культурно-освітніх перетворень. Як сподвижник царя Петра I, він був автором теорії модернізації Російської імперії в дусі освіченого абсолютизму й реформування церкви, підпорядкованої владі самодержця.

У 1721 р. Ф. Прокопович відкрив школу у своєму будинку в СанктПетербурзі, де під його наглядом і керівництвом навчалися сироти і бідні діти різних соціальних прошарків за складеними ним правилами й підручником. Школа Ф. Прокоповича була найкращою школою першої половини XVIII століття, мала свій статут, опікувалася насамперед якістю знань, які давала своїм вихованцям. Отож, на культурне-освітне середовище Росії значно вплинув процес українізації, зокрема школа ораторського мистецтва Ф. Прокоповича.

Упродовж XVII-XVIII століть з України до Росії прибуло від 10 до 20 тисяч науковців, професорів, учителів, наставників, вихователів, духовних осіб тощо. Однак із кінця XVIII століття потужний український вплив на російську систему освіти знівелювався, а дотепер українська наукова та освітянська думка була для Росії джерелом пізнавального поступу та постачання кадрів, особливо із середини XVII століття та впродовж майже усього XVIII століття ${ }^{8}$.

7 Данилевский В.В. Ломоносов на Украине. Ленинград : Газетно-журнальное и книжное издательство, 1954. 137 с.

8 Пономаревський С.Б. Українське шкільництво у Росії (1917-2010рр.): монографія. Чернігів : вид. Чернігівського державного інституту економіки і управління. 2012. 376 с. 


\section{2. Створення Санкт-Петербурзької академії наук}

В епоху Просвітництва у сфері професійної освіті окреслилася нова тенденція: відбувся централізований розвиток професійної системи навчання на основі наукових і педагогічних знань. Перші просвітницькі реформи в Росії були пов'язані 3 ім'ям Петра I. В епоху його царювання були закладені основи інтенсивного просвітницького руху та науки. Відкривалися нові навчальні заклади: Московська інженерна і хірургічна школи, Морська академія, медична, інженерна, артилерійська та інші.

Саме тому виникала потреба в підготовці кваліфікованих педагогів, оскільки в Росії того часу системи педагогічної освіти ще не існувало, вчителями ставали люди, які не були причетні до педагогічної діяльності. Запрошувалися також учителі із Західної Європи, здебільшого з Німеччини.

Важливим етапом у розвитку російської науки стало відкриття в 1724 р. Санкт-Петербурзької академії наук, що була створена за типом Паризької академії наук i Лондонського королівського товариства. Академія функціонувала як державне наукове товариство і стала вищою науковою установою Росії, центром російської науки, культури i педагогічної освіти, де реалізовувалися науководослідницький, техніко-прикладний, культурно-освітній і педагогічний напрями діяльності.

Першим президентом закладу був медик Л. Блюментрост, який піклувався про те, щоб діяльність Академії відповідала світовому рівню. Усі академіки першого складу були іноземцями і приїжджали в супроводі своїх студентів. Серед провідних іноземних науковців були математики М. і Д. Бернуллі, Х. Гольдбах, фізик Г. Бюльфінгер, астроном і географ Ж. Деліль, історик Г.Ф. Міллер, яких запросив ще Петро I. Серед іноземних членів академії були Х. Вольф, Ф. Вольтер, Д. Дідро, Б. Франклін, І. Кант, І. Гете, Ч. Дарвін та інші ${ }^{9}$.

У 1727 р. членом академії став Л. Ейлер - один із найвідоміших наукових корифеїв. Органом колективного обговорення й оцінки результатів досліджень була академічна конференція. Науковці мали свободу творчості й безмежні можливості друкувати наукові праці. Саме в Санкт-Петербурзі, що згідно з указом Петра I в 1703 р. набув статусу нової столиці Росії, було засновано першу Публічну бібліотеку, надруковано першу газету «Відомості», засновано Академію наук i перший дослідно-науковий музей - Кунсткамеру, який можна вважати прообразом науково-дослідних інститутів Росії.

Важливим етапом у розвитку російської науки стало відкриття 28 січня 1724 р. Санкт-Петербурзького університету у складі Академії

${ }^{9}$ История Императорской Академии Наук в Петербурге Петра Пекарского. Санкт-Петербург : Типография Императорской Академии Наук. 1873. 774 с. 
наук, що став одним із перших російських центрів розвитку науки і підготовки наукових кадрів у Росії. Із 1725 р. в Росії змінюється вектор ставлення до науки, можна стверджувати, що 3 цього часу відбувається прогресивний розвиток науки, російська наука отримує офіційне державне визнання.

Особлива увага в перші десятиліття XVIII століття приділяється розвитку досліджень у сфері фізико-математичних, історичних, медичних і географічних наук. Однак педагогіка в цей період не мала офіційного статусу самостійної науки, а існувала в межах філософії.

У 1726 р. при академії була заснована гімназія, яку можна вважати першою в Росії державною світською загальноосвітньою школою, що готувала гімназистів до вступу в університет і до кар'єри науковця. Гімназія складалася 3 двох відділень: німецька школа (3 роки навчання) i латинська школа (2 роки навчання). Основними навчальними предметами були такі: словесність, історія, географія, математика, природознавство та вивчення іноземних мов. У 1726 р. в гімназії навчалося 112 гімназистів, здебільшого це були діти зі знатних родин. За регламентом штату Академії наук, з 1747 р., окрім студентів і гімназистів, які навчалися за державні кошти, відвідувати лекції дозволялося всім охочим безкоштовно ${ }^{10}$.

Із-за кордону до Академії наук було запрошено 16 відомих європейських науковців, переважно 3 німецьких університетських осередків. Однак варто зазначити, що якщо в Західній Свропі початку XVIII століття спостерігався значний інтерес до природничо-наукових знань у зв'язку з інтенсивним поступом промисловості, розвитком філософських знань, то в державній Академії наук кріпосницької Росії навчання відбувалось на традиційних схоластичних засадах.

Досвід діяльності Академії наук дав підстави для створення через тридцять років першого в Росії світського вищого навчального закладу, наукового центру й центру розвитку педагогічної думки Московського університету. Академія наук також активно сприяла розвитку шкільної освіти. Протягом XVIII століття Академія брала участь в організації навчального процесу в усіх навчальних закладах Санкт-Петербурга, а професори Академії вели просвітницьковикладацьку діяльність. Аудиторії Академії наук були відкритими для публіки, а академіки зверталися до різних установ із пропозицією відбирати й індивідуально навчати одного-двох студентів за своєю спеціальністю для того, щоб підготувати своїх послідовників.

У 1746 p. президентом Академіі наук i мистецтв став К. Розумовський, який народився на хуторі Лемеші (нині - Козелецький

${ }^{10}$ История Императорской Академии Наук в Петербурге Петра Пекарского. Санкт-Петербург : Типография Императорской Академии Наук. 1873. 774 с. 
район Чернігівської області) у родині міського козака Г. Розума та очолював російську Академію наук 52 роки (1746-1798рр.).

У 1747 р. 3'явився перший Статут наукового товариства, що мав назву «Регламент Імператорської академії наук і мистецтв» (далі Статут), що визначав не лише структуру Академії наук, а й обов'язки кожного їі члена. Відповідно до Статуту, Академія наук поділялася на академію й університет. Відтоді академіки займалися винятково науковою роботою, а професори - викладацькою діяльністю. В академії було створено 3 класи: перший складався 3 астрономів і географів; до фізичного класу входили хіміки і біологи; третій клас був фізикоматематичним ${ }^{11}$.

До складу Академії наук мали ввійти 10 академіків, для кожного закладу призначався ад’юнкт і 10 почесних членів, які працювали за межами закладу. Ад’юнктами могли стати лише особи російського походження. При президентові К. Розумовському почали вперше працювати такі вітчизняні академіки, як М. Ломоносов, В. Тредіаковський, С. Крашенинников, Н. Попов, С. Котельников, С. Румовський, М. Софронов, А. Красильников, Г. Козицький, Н. Мотонис.

Згідно зі Статутом, на початку кожного року члени Академії наук пропонували плани наукових розробок у всіх галузях знань. Та відповідно до власних наукових спрямувань, пропонували президентові Академії наук новітні праці закордонних учених.

За роки президентства К. Розумовського професійних вершин досягла наукова діяльність М. Ломоносова, якого президент цінував і підтримував, розвивав його проекти, спрямовані на підвищення рівня наукової роботи Академії наук. Упродовж періоду керівництва К. Розумовського заклад (завдяки досягненням у галузі природничих і точних наук) посів почесне місце серед європейських академій.

Яскравим прикладом педагогічної майстерності були лекції самих академіків. На заняття запрошувалися всі охочі, про що повідомлялося в «Санкт-Петербурзьких відомостях» і в спеціально надрукованих оголошеннях, що розклеювалися на вулицях міста. Лекції 3 математики, які читав ад’юнкт з астрономії П. Іноходцев, викладалися російською мовою, а з фізики, які читав Л. Крафт, - французькою.

На розвиток російської науки і культури значно впливала діяльність академіка М. Ломоносова, який мріяв про створення при Академії наук спеціальних навчально-наукових центрів, у яких можна було б готувати висококваліфікованих спеціалістів, і був прихильником створення нової школи, в якій би поєднувалася загальноосвітня i практична підготовка молоді. Члени Академії активно працювали над написанням навчальних посібників для шкіл.

11 История Императорской Академии Наук в Петербурге Петра Пекарского. Санкт-Петербург : Типография Императорской Академии Наук. 1873. 774 с. 
Так, у перші роки роботи в Академії наук М. Ломоносов написав підручник «Стисле керівництво до красномовства». Як зазначила Г. Сагач, М. Ломоносов розрізняв такі фактори обдаровання оратора, як душевні, особливо гострий розум і пам'ять, фізичні (сильний та приємний голос, поставний вигляд). М. Ломоносов виділив такі знання елементів i структур публічної промови: вступ, тлумачення, твердження, завершення. Для успішного впливу на слухачів він рекомендував добре знати людину, стан оратора, стан слухачів (вік, стать, виховання, звички, рівень освіти тощо), силу красномовства. Учений уважав, що оратор повинен володіти своїми пристрастями, вміти збуджувати й гасити свої почуття, тоді слухачі будуть знати, що ця людина чесна, совісна, їй не є чужими ті пристрасті, які вона хоче збудити в слухачів ${ }^{12}$.

Уважаючи педагогіку невід'ємним складником світової і російської культури, М. Ломоносов обгрунтував принцип науковості як провідний принцип навчання і став засновником основ наукової педагогічної теорії. Учений одним із перших у Росії почав вивчати питання змісту i методів навчання, вважаючи, що способи навчання повинні відповідати віку дитини, а навчальний матеріал бути посильним. Ідея безперервності початкової, середньої і вищої освіти, яку запропонував М. Ломоносов, сприяла тому, що у кінці XVIII століття Сенат визнав створення гімназій і початкових училищ корисним для суспільства.

\section{3. Свропейські чинники реформування освіти в Росії}

У XVIII столітті в Європі утверджується ідея суспільного прогресу як провідна цінність епохи, умовою і критерієм якої був визнаний розум. Віра у всесилля розуму сформувала культ знання, визнаного однією $з$ провідних цінностей того часу. Прийняття просвітницьких ідей вимагало від верховної влади звернути увагу на діячів науки, використовувати їх інтелектуальний потенціал у педагогічній галузі. Деякі монархи з метою модернізації своїх держав здійснювали реформи «зверху», керуючись при цьому ідеологією Просвітництва.

Період російської історії XVIII століття називають «Століття Просвітництва». Державна освітня політика Росії XVIII століття здійснювалася на основі принципу централізації, а також у процесі реалізації адміністративних реформ регіонального управління та формування освіченої еліти в регіонах. У цей період поширюється інтерес до наук, наукові дослідження почали проводити не лише науковці-члени академії наук, але й учителі гімназій, викладачі університетів.

12 Сагач Г.М. Риторика : навчальний посібник. Київ : Вид. дім «Ін-Юре», 2000. 565 c. 
У 60-80-ті pp. XVIII століття, за правління Катерини II, була зроблена спроба вийти на належний освітній і культурний рівень, догнати Свропу у сфері інтелектуального розвитку суспільства, тому що в цей період західноєвропейське «Просвітництво» накопичило «банк» різноманітних ідей, підходів, методик у галузі навчання та виховання нового покоління. До Росії стали запрошувати відомих учених, педагогів-практиків із західноєвропейських країн.

Безперечним є внесок у розвиток освіти Росії видатного фізика, астронома, математика, громадського і державного діяча, професора астрономії Берлінської академії наук Ф. Епінуса, якого ще за життя стали вважати класиком науки. Учений зробив неоціненний внесок устворення російської системи народної освіти і запропонував максимально точно відтворити австрійську модель реформи, яка виявилася вдалою.

Головною запорукою успіху шкільної реформи вчений уважав професійну підготовку вчителів, які б стали майстрами і розуміли чому, яким чином i за якою науково обгрунтованою методикою навчати учнів. Учений звертав увагу на те, що в Росії немає достатньої кількості вчителів, здатних майстерно робити свою справу, тому він наполягав на необхідності термінового надання вчителям якісної освіти. Для успішної діяльності навчальних закладів учений радив запросити підготовлених учителів з австрійських провінцій, які знали слов'янські наріччя і діалекти та були православної віри.

Ф. Епінус запропонував упроваджувати австрійську систему навчання, наполягаючи на негайному заснуванні трьох або чотирьох кращих учительських семінарій у Петербурзі, Москві, Казані, Києві. Навчатися майбутні вчителі мали б за державні кошти. Учений уважав за необхідне заснувати вищу навчальну комісію, в обов'язки якої мало входити старанне вивчення шкільної справи в Австрії і складення плану шкільної реформи в Російській імперії, який би йй відповідав; вжити заходів для організації трьох-чотирьох учительських семінарій; почати перекладати австрійські підручники, пам'ятаючи, що вони потребують деяких змін, ураховуючи національні особливості ${ }^{13}$.

У 1782 p. за дорученням Катерини II було створено Комісію із запровадження народних училищ, яка мала зреалізувати такі завдання: скласти план народних училищ i розробити їх статут, написати підручники або перекласти російською мовою вже наявні; підготувати вчителів; відкрити школи у всій імперії. Головою Комісії був призначений уродженець Чернігівщини, вихованець КиєвоМогилянської академії, сенатор, таємний радник граф П. Завадовський, який після того, як Комісія народних училищ була перетворена

13 Бобынин В. В. Эпинус, Франц-Ульрих-Теодор. Энциклопедический словарь Брокгауза и Ефрона: в 86 т. (82 т. и 4 доп.). Санкт-Петербург : издатель АО Ф.А. Брокгауз - И.А.Ефрон. 1890-1907. 
в Міністерство народної освіти Російської імперії, став першим міністром народної освіти.

До складу Комісії ввійшли академік Ф. Епінус та кабінет-секретар імператриці - сенатор П. Пастухов. У 1782 р. до Росії (на запрошення Катерини II) приїхав відомий австрійський педагог Ф. Янкович-деМирієво. Він деякий час обіймав посаду директора головної народної школи та учительської семінарії в Санкт-Петербурзі, був членом Російської академії, консультантом із питань шкільної реформи та виконував найбільш відповідальну і складну роботу з розроблення та реалізації реформи.

Ф. Янкович працював у Росії тридцять років та переклав російською мовою австрійські й німецькі інструкції для вчителів, шкільні статути, підручники, що дозволило російським педагогам і державним діячам ознайомитися із західноєвропейським досвідом організації шкільної справи (Воронов, 1858). Саме в цей історичний період було започатковано професійну підготовку вчителів та вжито заходів щодо вдосконалення їx педагогічної майстерності. Ф. Янкович особисто займався підготовкою вчителів для цих шкіл, але тільки після смерті Катерини II імператор Павло I призначив Ф. Янковича членом Комісії ${ }^{14}$.

У 1783 р. в Санкт-Петербурзі було опубліковано перший підручник iз педагогіки відомого австрійського педагога «Керівництво вчителям першого і другого класу», адаптований до російських умов і традицій та перекладений із німецької російською мовою Ф. Янковичем.

У підручнику пояснювалися сутність і принципи організації класноурочної системи навчання, яка раніше не використовувалися російськими вчителями, обгрунтовувалася теорія дидактики. Видання складалося 3 чотирьох частин. Перша частина була присвячена методиці роботи з класом. Учителі зобов'язувалися працювати з усім класом, а не навчати кожного поодинці. Друга частина містила окремі методики навчальних предметів, які вивчалися в народному училищі. У третій частині характеризувалась особистість учителя i його професійні якості. У четвертій частині йшлося про організацію всього шкільного життя, суворо регламентувалася діяльність учителя ${ }^{15}$.

Особлива увага в підручнику приділялася особистості вчителя, його чеснотам, а саме: миролюбності й порядності, постійній бадьорості духу й тіла, вірності самодержавному устрою і своїй соціальній приналежності, християнській доброчесності, тілесному здоров'ю і працьовитості.

${ }^{14}$ Воронов А. Федор Иванович Янкович де Мириево, или Народные училища в России при императрице Екатерине II-й. Санкт-Петербург : тип. Э. Праца, 1858. 168 с.

15 Руководство учителям первого и второго класса народных училищ Российской империи, изданное по Высочайшему повелению царствующей Императрицы Екатерины Вторыя. Санкт-Петербург, 1783. VIII, 114, 31 с. 
Заняття розпочиналися 3 молитви, навчання було спільним для хлопчиків і дівчаток, хоча сиділи вони порізно. Було докладно розписано правила поведінки поза школою і вдома, які грунтувалися на традиціях російського православного виховання і правилах хорошого тону, прийнятого у світській сфері того часу. Тілесні покарання були заборонені.

Перший у Росії навчальний заклад із підготовки професійних педагогів - учительська семінарія - було відкрито в Санкт-Петербурзі (1783 р.), директором семінарії був призначений Ф. Янкович-де-Мирієво.

У 1786 р. був затверджений «Статут народних училищ у Російській імперії», що заклав основи становлення державної загальноосвітньої школи і став важливим документом для розвитку педагогічної думки Росії XVIII століття.

Статут регламентував всі напрями діяльності народних училищ, що створювалися в державі, і складався 39 розділів: 1) про головні народні училища; 2) про малі народні училища; 3) про посади вчителів; 4) про учнів; 5) про попечителів народних училищ; 6) про доглядачів; 7) про господарську частину; 8) про головний уряд училищ ${ }^{16}$.

Згідно зі Статутом, було вирішено у всіх містах і великих селах Росії відкрити народні училища двох типів: у губернських містах головні народні училища 3 5-річним строком навчання, а в уїзних містах і селах - малі народні училища з 2-річним терміном.

Центральне місце в Статуті посідав розділ «Про посади вчительські», де було сформульовано вимоги до педагогів училищ. Головними рисами шкільного вчителя вважалися такі: правочинство і благочестя, міцні наукові знання, яким учитель повинен навчати, здатність їх викладати зрозуміло і виразно, любов до юнацтва (спільна 3 поміркованою дисциплінованістю); крім того, вчитель повинен мати велике терпіння й досконалу безкорисливість. Професійні обов'язки вчителя були чітко регламентовані, він мусив точно дотримуватися навчального плану і викладати за підручником.

Статутом було затверджено класно-урочну систему викладання. Учителеві пропонувалося працювати одночасно з усім класом. Після викладу нового матеріалу потрібно було вміло здійснити «опитування». У російській школі навчання здійснювалося за розкладом, були наявні класна дошка, крейда i класний журнал, у якому вказувалися відвідування й успіхи учнів, установлювалися певні дні початку занять і терміни проведення екзаменів.

Підвищенню рівня професійної підготовки вчителів сприяло те, що (відповідно до Статуту) головні народні училища мусили готувати кадри для малих училищ. Сторонні особи, які мали бажання стати вчителями, мусили обов'язково скласти іспит при головних училищах і

16 Полное собрание законов Российской империи с 1649 года. Т. 21. СанктПетербург : Типография 2 отделения Его Императорского Величества, 1830-1851. 
лише після цього вони отримували атестат і розпочинали виконання учительських обов'язків.

Статут народних училищ 1786 p. започаткував державну систему безкоштовних загальноосвітніх міських шкіл у Росії, що мали позастановий характер. Шкільний статут грунтувався на досягненнях європейської педагогіки, поєднував їх із вимогами російської дійсності, характеризував оригінальну за формою і змістом систему народної освіти Росії. У цей період спостерігалася взаємозумовленість, взаємозалежність суспільства, державної політики й освіти.

\section{ВИСНОВКИ}

На розвиток та становлення системи освіти в Росії протягом багатьох років значно впливала Києво-Могилянська колегія, а потім Києво-Могилянська академія, яка була детермінантом російського культурного і навчального простору: використовувалися підручники викладачів Києво-Могилянської академії, відбувалося студіювання російських студентів, вихованці закладу, які працювали в Росії, пропонували оригінальні просвітницькі й освітні проекти, що дозволило наприкінці століття закласти підгрунтя для подальшого вдосконалення освіти, науки і культури в цілому.

У XVIII столітті відбувалося зближення Росії із західноєвропейськими державами в політичному й соціально-економічному контекстах, що сприяло загальнокультурному розвитку держави і європеїзації російського соціуму. Провідною тенденцією становлення системи освіти в Росії XVIII століття була іiі інтеграція до європейського освітнього простору, що зумовило активізацію одного 3 напрямів розвитку освіти - створення Санкт-Петербурзької Академії наук і першого світського вищого навчального закладу - академічного університету при цій академії. Проекти шкільних реформ, розроблені членами Академії наук відповідно до їх науково-педагогічних поглядів, характеризували державний підхід, масштабність, зацікавленість і продуманість задумів.

Санкт-Петербурзька академія наук, спираючись на досягнення європейської, а також української культурної, науково-освітньої думки, духовного розвитку, стала акумулятором продуктивних ідей, постійно пропонуючи оригінальні просвітницькі й освітні проекти, розробляючи головні напрями кардинальних змін шкільної справи, що дозволило наприкінці століття закласти підгрунтя для подальшого вдосконалення освіти, науки й культури в цілому. У XVIII столітті відбулася перша в історії Росії шкільна реформа, результатом якої стало створення основ системи народної освіти держави. Виявлено, що створенню Комісії народних училищ в Росії передувало вивчення й узагальнення європейського (переважно австрійського) досвіду проведення шкільної реформи. 


\section{АНОТАЦІя}

У статті репрезентовано результати історико-педагогічного дослідження становлення системи освіти Росії XVIII століття. Виявлено потужний український вплив на розвиток освіти, просвітництва, культури на межі XVII і XVIII століть, який базувався на поглядах філософів, педагогів, психологів, церковних, громадських, освітніх, культурних діячів, вихідців з України.

На основі положень методологічних підходів (системнохронологічного, історичного, антропологічного тощо) і принципів науковості, об'єктивності, історизму, системності, єдності теорії і практики виявлено тенденції розвитку системи освіти в Росії XVIII століття. 3'ясовано, що розвиток і становлення системи освіти Росії періоду, що досліджується, зазнало впливу західноєвропейської реформаторської філософсько-педагогічної думки. Це сприяло екстраполяції в російську педагогічну теорію й практику освіти ідей і позитивного гуманістичного досвіду європейських «нових шкіл».

Узагальнено творчий внесок діячів освіти, науки, культури Росії періоду, що досліджується, та представників західної наукової еліти в розбудову системи освіти Росії, що стало важливою передумовою культурного розквіту та духовного оновлення суспільства. З'ясовано, що зародження, розвиток i створення російської професійної підготовки вчителів почалося 3 діяльності першої установи з управління освітою - Комісії із запровадження народних училищ (1782) та затвердження Статуту народних училищ (1786).

\section{ЛІТЕРАТУРА}

1. Бобынин В.В. Эпинус, Франц-Ульрих-Теодор. Энциклопедический словарь Брокгауза и Ефрона: в 86 т. (82 т. и 4 доп.). СанктПетербург: издатель АО Ф.А. Брокгауз - И.А. Ефрон. 1890-1907.

2. Веревкин М.И. Жизнь покойного Михаила Васильевича Ломоносова. М.В. Ломоносов в воспоминаниях и характеристиках современников. Москва : Акад. наук СССР, 1962. С. 42-51.

3. Владимирский-Буданов М.Ф. Государство и народное образование в России XVIII века.. Ярославль : Тип. Губернского Правления, 1874. Книга 8. С. 193-330.

4. Воронов А. Федор Иванович Янкович де Мириево, или Народные училища в России при императрице Екатерине II-й. СанктПетербург : тип. Э. Праца, 1858. 168 с.

5. Данилевский В.В. Ломоносов на Украине. Ленинград : Газетножурнальное и книжное издательство, 1954. 137 с.

6. История Императорской Академии Наук в Петербурге Петра Пекарского. Санкт-Петербург : Типография Императорской Академии Наук. 1873.774 c.

7. Из истории учебных реформ Императрицы Екатерины II. Известия по народному образованию. 1909. Ч. ХХ. С. 299-307. 
8. Исторические очерки и рассказы С.Н. Шубинского. СанктПетербург : тип. А.С. Суворина, 1908, 712 с.

9. Лавріненко О.А. Історія педагогічної майстерності: навчальний посібник. Київ: Богданова А.М., 2009. 328 с.

10. Мільто Л. Педагогічна майстерність в Росії: історія, теорія, практика (середина XVIII-XX ст.) : монографія. Київ : «Фенікс», 2018. $612 \mathrm{c}$.

11. Пекарский П.П. Введение в историю просвещения в России XVIII столетия. Санкт-Петербург : Тип. Акад. наук, 1862.578 с.

12. Полное собрание законов Российской империи с 1649 года. Т. 21. СПб.: Типография 2 отделения Его Императорского Величества, $1830-1851$.

13. Пономаревський С.Б. Українське шкільництво у Росії (19172010 рр.): монографія. Чернігів : вид. Чернігівського державного інституту економіки і управління. 2012. 376 с.

14. Рождественский С.В. Из истории учебных реформ императрицы Екатерины II. СПб. : Сенатская типография. 1909. 97 с.

15. Руководство учителям первого и второго класса народных училищ Российской империи, изданное по Высочайшему повелению царствующей Императрицы Екатерины Вторыя. Санкт-Петербург, 1783. VIII, 114, $31 \mathrm{c.}$

16. Сагач Г.М. Риторика : навчальний посібник. Київ : Вид. дім «ІнЮpe», 2000. 565 c.

17. Смирнов С.К. История Московской славяно-греко-латинской академии. Москва : тип. В. Готье, 1855. 428 с.

18. Трубецкой Н.С. К украинской проблеме. Евразийский современник. Книга V. Париж, 1927. С. 165-184.

\section{Information about the author: Milto L. O.,}

Doctor of Pedagogical Sciences, Associate Professor, Professor at the Department of Pedagogy and Psychology of Higher Education

National Pedagogical Dragomanov University 9, Pyrohova str., Kyiv, 02000, Ukraine 